\title{
Selected Parametric Effects on Materials Flammability Limits
}

\author{
David B. Hirsch, ${ }^{1}$ Alfredo Juarez, ${ }^{2}$ Gary J. Peyton, ${ }^{3}$ Susana A. Harper ${ }^{4}$ \\ NASA White Sands Test Facility, Las Cruces, NM, 88004 \\ and \\ Sandra L. Olson ${ }^{5}$ \\ NASA Glenn Research Center, Cleveland, $\mathrm{OH}, 44135$
}

\begin{abstract}
NASA-STD-(I)-6001B Test 1 is currently used to evaluate the flammability of materials intended for use in habitable environments of U.S. spacecraft. The method is a pass/fail upward flame propagation test conducted in the worst case configuration, which is defined as a combination of a material's thickness, test pressure, oxygen concentration, and temperature that make the material most flammable. Although simple parametric effects may be intuitive (such as increasing oxygen concentrations resulting in increased flammability), combinations of multi-parameter effects could be more complex. In addition, there are a variety of material configurations used in spacecraft. Such configurations could include, for example, exposed free edges where fire propagation may be different when compared to configurations commonly employed in standard testing. Studies involving combined oxygen concentration, pressure, and temperature on flammability limits have been conducted and are summarized in this paper. Additional effects on flammability limits of a material's thickness, mode of ignition, burn-length criteria, and exposed edges are presented. The information obtained will allow proper selection of ground flammability test conditions, support further studies comparing flammability in 1-g with microgravity and reduced gravity environments, and contribute to persuasive scientific cases for rigorous space system fire risk assessments.
\end{abstract}

\section{Introduction}

NASA-STD-(I)-6001B Test 1 is currently used to evaluate the flammability of materials intended for use in habitable environments of U.S. spacecraft. ${ }^{1}$ The method is a pass/fail upward flame propagation test conducted in the worst case configuration, which is defined as a combination of a material's thickness, test pressure, oxygen concentration, and temperature that make the material most flammable. Although simple parametric effects may be intuitive (such as increasing oxygen concentrations resulting in increased flammability), combinations of multiparameter effects could be more complex. Such a situation could arise, for example, on predicting a worst case when comparing a condition of higher oxygen concentration at a lower total pressure with a condition of lower oxygen concentration at a higher pressure. Similarly, a material configuration having a lower thickness may be intuitively more flammable under most conditions; however, there might be a minimum coating thickness below which the material may not ignite, possibly due to insufficient fuel available for gasification. In addition, there are a variety of material configurations used in spacecraft. Such configurations could include, for example, exposed free edges

${ }^{1}$ Aerospace Engineer and Branch Manager, Aerospace Materials and Flight Hardware Testing, NASA Laboratories Department, WS-803, NASA White Sands Test Facility, Las Cruces, New Mexico, 88004.

2 Materials Test Engineer, NASA Laboratories Department WS-800, NASA White Sands Test Facility, Las Cruces, New Mexico, 88004.

3 Materials Test Coordinator, NASA Laboratories Department WS-803, NASA White Sands Test Facility, Las Cruces, New Mexico, 88004.

${ }^{4}$ NASA Standard Testing Manager, NASA Laboratories Office, WS-800, NASA White Sands Test Facility, Las Cruces, New Mexico, 88004.

${ }^{5}$ Aerospace Engineer, NASA Glenn Research Center, Cleveland, Ohio, 44135. 
where fire propagation may be different when compared to configurations commonly employed in NASA standard flammability testing.

Total pressure effects on oxygen concentration thresholds have been investigated. ${ }^{2}$ For materials with maximum oxygen concentrations (MOCs) at which extinguishment occurs in the range of 25-35\% oxygen, the data indicate there is an approximately linear dependence of MOCs on total pressure $\mathrm{P}_{\mathrm{t}}$ having the form:

$$
\mathrm{MOC}=\mathrm{mP}_{\mathrm{t}}+\mathrm{b}
$$

The values for the slope, $\mathrm{m}$, and intercept, $\mathrm{b}$, were determined. The maximum slope was $-0.975 \%$ oxygen/psia and the minimum was $-0.251 \%$ oxygen/psia, with an average of $-0.607 \%$ oxygen/psia. It was recommended to use only the minimum MOC, i.e., 25.6\% oxygen as a conservative estimate, indicating that the oxygen concentration limit at 14.7 psia cannot be set higher than approximately $25.6 \%$ oxygen without invalidating the material's flammability certification in 30\% oxygen at 10.2 psia for at least some materials. For testing performed in the mid to late $80 \mathrm{~s}$ while upgrading the Space Shuttle from $25.9 \%$ oxygen at 14.7 psia to $30 \%$ oxygen at 10.2 psia, there was an underlying assumption that $30 \%$ oxygen at 10.2 psia would provide a more flammable environment than conditions of $25.9 \%$ oxygen at 14.7 psia. For at least one of the materials tested, the data indicate that a material with an MOC of 30\% oxygen at 10.2 psia would fail NASA-STD-(I)-6001B Test 1 at $25.9 \%$ oxygen and 14.7 psia. The implication is that transitory oxygen concentration/pressure conditions should be considered carefully while transitioning the spacecraft from one environment to another to reduce the possibility of exposing spacecraft materials to potentially flammable environments.

Pressure flammability thresholds in $99.8 \%$ oxygen were determined. ${ }^{3}$ For the materials tested, the maximum total pressure flammability threshold ranged from 0.4 to 0.9 psia before combustion was sustained. Although no data existed previously, the pressure flammability threshold of 0.4 psia is appreciably lower than had been expected based on general testing experience; even the chemical igniter's pressure flammability threshold was higher (0.7 psia).

Temperature effects on the upward limiting oxygen index (ULOI) have been investigated ${ }^{4}$ to determine the magnitude of lowering ambient temperature flammability oxygen concentration thresholds upon a failure such as the electronics overheating. The ULOI is the oxygen concentration where there is approximately $50 \%$ probability for a material to extinguish. When compared with tests at ambient temperatures, preheating the material to $200{ }^{\circ} \mathrm{F}$ resulted in ULOI lowering from 49 to 40.8 for polytetrafluoroethylene. The decrease was less for materials with lower ULOIs (for materials with ULOI at ambient temperature of 23 , the ULOI decreased approximately $10 \%$ at $\left.200{ }^{\circ} \mathrm{F}\right)$.

This paper provides additional information for selecting worst case 1-g flammability test conditions and better understanding configurational effects for supporting space system fire risks assessments. Testing has also been conducted to support selecting test materials and sample configurations for flight experiments to correlate 1-g flammability data with data in specific spacecraft environments (microgravity, forced convective flow). Flight test restrictions (such as limited space in closed chambers potentially leading to oxygen depletion) will prevent testing large standard-size NASA-STD-(I)-6001B samples. Smaller size samples will have to be used, with different pass/fail criteria than those prescribed in the standard. Consequently, correlation of flammability threshold data obtained with special sample configurations (i.e., rods, narrow samples not supported on the sides by the sample fixture), ignition source, etc., and data obtained under standard conditions, has been considered necessary to extend the applicability of flight experiment conclusions to standard test results. The tests conducted include effects on oxygen concentration flammability thresholds of material thickness, mode of ignition, sample geometry, exposed edges vs. standard sample mounting, and pass/fail criteria.

\section{Experimental Apparatus and Procedures}

The equipment used and the experimental approach has been described previously. ${ }^{2}$ Upward flammability threshold tests were conducted in initial quiescent environments in a closed 1400-L flammability chamber connected to vacuum, oxygen, and nitrogen supplies. The testing was conducted sequentially as recommended by ASTM D 2863 using a step size of $1 \%$ oxygen by volume. ${ }^{5}$ With the exception of tests focused on obtaining information on pass/fail criteria effects, the NASA-STD-(I)-6001B Test 1 burn length criterion was used. A sample was considered self-extinguishing if its burn length was at least 6 in. The tests for evaluating pass/fail criteria effects were conducted 
using 1, 2, and 6-in. pass/fail burn length criteria. The ULOIs were calculated with the "up-and-down method for small samples.” In this study, MOCs that consistently result in self-extinguishment, i.e., where all samples (at least five) pass a specific burn length criterion, were determined. Except as noted, the tests were conducted at 14.7 psia.

Materials tested are summarized in Table 1. Except as noted and for testing rods, the samples were 6-in. long and 2.5-in. wide. With the exception of exposed-edge tests and narrow $1 / 2$-in. wide samples, for the tests on flat samples, a standard wing-nut fixture was employed. ${ }^{1}$ Tests with chemical igniters were standard; the tests with hot-wire ignition used 20 AWG KA1 NiChrome wire set up in a flat coil configuration resembling a sine curve with roughly four periods. A programmable DC power supply was used to deliver $8.5 \mathrm{~V}$ to the specimen for 8 seconds. The tests on rods and $1 / 2$-in. wide samples were conducted on 7 -in. long samples to allow top-supporting. The sample holding fixture for rods consisted of a wing-nut fixture with a tube fitted with a set screw to support the sample vertically; for hot-wire ignition tests of rod and $1 / 2$-in. wide configurations, 4.5-in. of 20 AWG KA1 Nichrome wire was wrapped three times around the bottom of the sample. Mounting and igniter placement for exposed-edge tests, and for tests with hot-wire ignitions, are shown in Figure 1. Except as noted for hot-wire ignition tests, the coil was connected to a voltage source capable of providing 15 Amps root-mean-square (RMS).

Table 1. Selected polymeric materials evaluated in this study.

\begin{tabular}{|c|c|c|c|}
\hline $\begin{array}{c}\text { Generic or } \\
\text { Trade Name }\end{array}$ & Acronym & $\begin{array}{l}\text { Chemical Name or } \\
\text { Composition }\end{array}$ & Additional Material Information \\
\hline Ultem $^{\circledR a} 1000$ & PEI & polyetherimide & $\begin{array}{l}\text { Film, Tekra Corp. P/N DLI1648, 0.01-in. } \\
\text { thick }\end{array}$ \\
\hline Kapton $^{\circledR b} \mathrm{HN}$ & PI & polyimide & $\begin{array}{l}\text { film, DuPont High-Performance Materials, } \\
0.005 \text {-in. thick }\end{array}$ \\
\hline Zytel $^{\circledR b} 42$ & PA & polyamide & plastic, A.L. Hyde Co., 0.064-in. thick \\
\hline Nylon 101 & PA & polyamide & $\begin{array}{l}\text { plastic, Quadrant Engineering Plastic } \\
\text { Products, 1/8-in. dia rod }\end{array}$ \\
\hline Melinex $^{\circledR C} 515$ & PET & polyethylene terephtalate & film, DuPont Teijin Films, 0.005-in. thick \\
\hline Epoxy/glass & - & epoxy/fiberglass & $\begin{array}{l}\text { Laminate, NEMA G-11, H-23842, } \\
\text { Westinghouse, 0.064-in. thick }\end{array}$ \\
\hline Polypropylene & PP & polypropylene & $\begin{array}{l}\text { plastic, Quadrant Engineering Plastic } \\
\text { Products, 1/8-in. dia rod }\end{array}$ \\
\hline Silicone (for edge effects) & MQ & polydimethylsiloxane & elastomer, Rubberite Corp., 0.062-in. thick \\
\hline $\begin{array}{l}\text { Silicone (for durometer } \\
\text { effects) }\end{array}$ & MQ & polydimethylsiloxane & $\begin{array}{l}\text { elastomer, 30, 40, 50, 60, and 70- } \\
\text { durometer, Dow 27013-V Black, 27014-V } \\
\text { Green, 27015-V Red, 27016-V Red, } \\
\text { 27017-V Red, respectively, Tech Products } \\
\text { Corp., 0.25-in. nominal thickness }\end{array}$ \\
\hline $\begin{array}{l}\text { Silicone (for thickness, } \\
\text { mode of ignition, and } \\
\text { pass/fail criteria effects) }\end{array}$ & MQ & polydimethylsiloxane & $\begin{array}{l}\text { elastomer, SSP-M823, SSP Corp., 0.004, } \\
0.010,0.014,0.024 \text {, and } 0.040 \text {-in. thick }\end{array}$ \\
\hline Polyvinylchloride & PVC & polyvinylchloride & $\begin{array}{l}\text { Plastic, Quadrant Engineering Plastic } \\
\text { Products, 1/8-in. dia rod }\end{array}$ \\
\hline Polyvinylchloride & PVC & polyvinylchloride & $\begin{array}{l}\text { plastic, Boltaron Performance Products, } \\
\text { LLC, 0.061-in. thick }\end{array}$ \\
\hline
\end{tabular}


Table 1. Selected polymeric materials evaluated in this study. (cont'd)

\begin{tabular}{|c|c|c|c|}
\hline $\begin{array}{c}\text { Generic or } \\
\text { Trade Name } \\
\end{array}$ & Acronym & $\begin{array}{c}\text { Chemical Name or } \\
\text { Composition } \\
\end{array}$ & Additional Material Information \\
\hline Polymethylmetacrylate & PMMA & polymethylmetacrylate & $\begin{array}{l}\text { clear extruded or cast plastic, U.S. Plastic } \\
\text { Corp. } 1 / 4 \text {-in. dia rod }\end{array}$ \\
\hline Acetron ${ }^{\circledR d}$ GP & POM & polyoxymethylene & $\begin{array}{l}\text { plastic, Quadrant Engineering Plastic } \\
\text { Products U.S,A., Inc., 1/8-in. dia rod }\end{array}$ \\
\hline $\operatorname{Delrin}^{\circledR b}$ & POM & polyoxymethylene & plastic, A.L. Hyde Co., 0.054-in. thick \\
\hline Nitrile & NBR & polyacrylonitrile-butadiene & elastomer, Rubberite Corp., 0.063-in. thick \\
\hline Victrex ${ }^{\circledR C}$ PEEK & PEEK & polyether ether ketone & film, A.L. Hyde Co., 0.010-in. thick \\
\hline \multicolumn{4}{|c|}{$\begin{array}{l}\text { a } \text { Ultem }^{\circledR} \text { is a registered trademark of SABIC Innovative Plastics, Inc. The Netherlands. } \\
{ }^{\mathrm{b}} \text { Kapton }^{\circledR} \text {, Zytel }{ }^{\circledR} \text {, and Delrin }{ }^{\circledR} \text { are registered trademarks of E. I. Du Pont de Nemours and Company, Wilmington, DE. } \\
{ }^{\mathrm{c}} \text { Melinex }^{\circledR} \text { and Victrex }{ }^{\circledR} \text { are a registered trademarks of Imperial Chemical Industries Limited, London, England. } \\
{ }^{\mathrm{d}} \text { Acetron }{ }^{\circledR} \text { is a registered trademark of Polymer Corporation, Reading, PA. }\end{array}$} \\
\hline
\end{tabular}

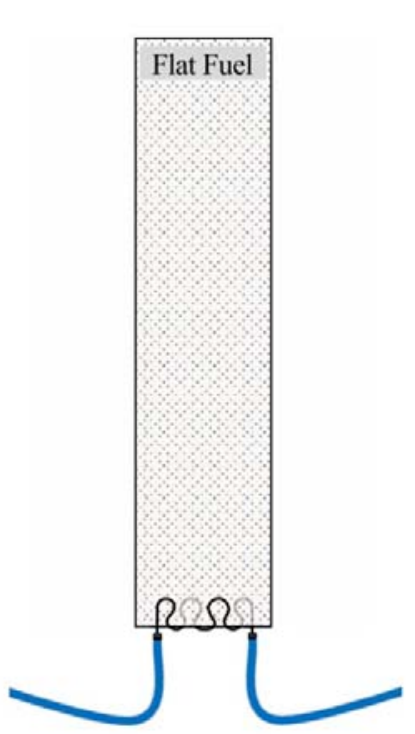

A

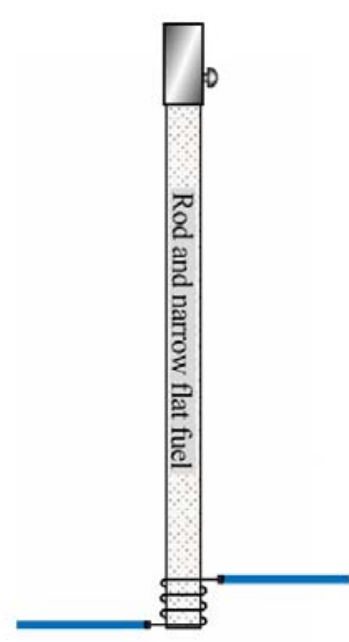

B

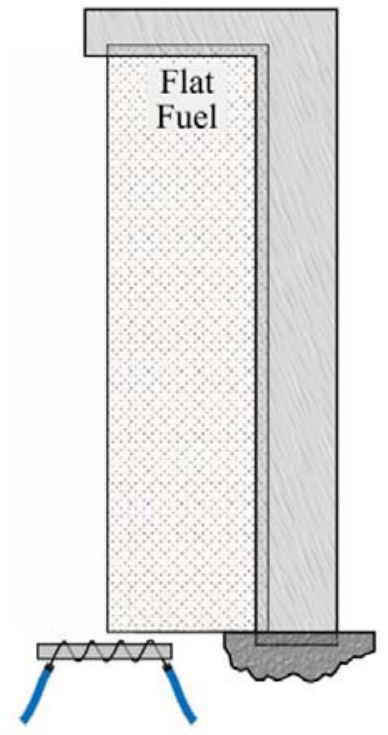

$\mathrm{C}$

A - Hot-wire igniter configuration for flat samples with standard width (2.5-in. wide). The wing-nut sample holder is not shown for clarity.

B - Hot-wire igniter configuration for rods and narrow flat samples (1/2-in. wide).

$\mathrm{C}$ - Chemical igniter positioning for tests with exposed-edge samples.

\section{Figure 1. Placement of ignition source and sample mounting.}

\section{Results and Discussion}

Tables 2 through 5 provide information that may be used in evaluating spacecraft fire risks. The mode of ignition did not result in significant difference in oxygen concentration flammability thresholds (Table 2); both the chemical igniter and the hot wire ignited the materials at the highest oxygen concentrations where eventually the flame 
extinguished. Additional information is being analyzed to determine ignition delays and ignition time differences between the two modes of ignition.

The flammability thresholds decreased with decreasing thickness for MQ (Table 3). Additional materials are evaluated to confirm this result, which validates the NASA-STD-(I)-6001B recommendation to test materials in the thinnest configuration to simulate worst thickness usage conditions. It is suspected the magnitude of the thickness effects depend on the magnitude of the MOC values, a hypothesis that will be verified when additional data is available.

Limited tests conducted indicate that the material durometer did not significantly affect the oxygen concentration flammability thresholds (Table 4). The tests with exposed edges resulted mostly in higher oxygen concentration thresholds than the samples tested in standard NASA-STD-(I)-6001B configuration, although the difference was very small (Table 5). Only tests on PVC resulted in significant difference. Although the ULOIs for the two configurations were approximately the same, the MOC increased from 35 for the standard test configuration to 39 for the exposed edge. This somewhat surprising result will need to be confirmed with further tests. The edge flame gets a greater oxygen supply from the outer free stream velocity by convection and diffusion and has a more efficient heat transfer rate to the sample and could result in higher flame spread in microgravity for exposed edges. ${ }^{6}$ On the other side, near-extinction conditions may be controlled by other factors than those controlling flame propagation rate under stable burning conditions. To complicate the picture, extinguishment-controlling factors could be different in 1-g than in microgravity.

Table 2. Effects of mode of ignition on flammability thresholds.

\begin{tabular}{lcccc}
\hline \multicolumn{1}{c}{ Material } & \multicolumn{2}{c}{ Chemical Igniter } & Hot-wire \\
\cline { 2 - 4 } & ULOI & MOC & 21.3 & MOC \\
\hline PET $^{\mathrm{a}}$ & 21.5 & 20 & 23.5 & 20 \\
PEI $^{\text {a }}$ & 26.5 & 24 & 22.5 & 23 \\
MQ, 0.040 in. thick & 23.4 & 22 & 22.4 & 20 \\
MQ, 0.024 in. thick & 22.8 & 20 & 28.7 & 22 \\
PI & 27.2 & 26 & 18.9 & 21.1 \\
PEEK & 20.8 & 19 & & 18 \\
PMMA, extruded, & 19.5 & & \\
1/4-in. dia rod & & \\
\hline a & PET and PEI were tested at 10.2 psia in a NASA Glenn Research Center (GRC) reduced-gravity fixture and ignited with a hot wire following \\
the GRC protocol. The GRC reduced gravity specimen holder was constructed from stainless steel and had a series of round magnets around \\
the parameter of the sample. The test samples were sandwiched between the two fixture plates and held in place by the magnets. A sheet of \\
mica adhered to each fixture plate isolated the sample from the sample fixture. Each test sample was roughly 4-in. wide and 6-in. long. When \\
placed in the fixture, there was a 2-in. wide flame path with ignition occurring at the bottom of the sample. A 29 gauge KA1 (Kanthal) wire \\
was used to ignite the. specimen. This wire was set up in a flat coil configuration resembling a sine curve with eight periods. To simulate the \\
reduced gravity test protocol, a programmable DC power supply was used to deliver a short burst of 26 V for 0.5 s followed by a burst of 15 V \\
for 3 s.
\end{tabular}

Table 3. Effects of sample thickness on flammability thresholds.

\begin{tabular}{lcccccccccc}
\hline \multirow{2}{*}{ Material $^{\mathrm{a}}$} & \multicolumn{2}{c}{$4 \mathrm{mil}$} & \multicolumn{2}{c}{$10 \mathrm{mil}$} & \multicolumn{2}{c}{$14 \mathrm{mil}$} & \multicolumn{2}{c}{$24 \mathrm{mil}$} & \multicolumn{2}{c}{$40 \mathrm{mil}$} \\
\cline { 2 - 22 } & ULOI & MOC & ULOI & MOC & ULOI & MOC & ULOI & MOC & ULOI & MOC \\
\hline MQ & 17.5 & 17 & 19.7 & 18 & 21 & 19 & 22.8 & 20 & 23.4 & 22 \\
\hline${ }^{a} \quad$ Additional materials are being tested. & & & & & & & &
\end{tabular}

Table 4. Effects of material Durometer on flammability thresholds.

\begin{tabular}{|c|c|c|c|c|c|c|c|c|c|c|}
\hline \multirow[t]{2}{*}{ Material } & \multicolumn{2}{|c|}{30 Durometer } & \multicolumn{2}{|c|}{40 Durometer } & \multicolumn{2}{|c|}{50 Durometer } & \multicolumn{2}{|c|}{60 Durometer } & \multicolumn{2}{|c|}{70 Durometer } \\
\hline & ULOI & MOC & ULOI & MOC & ULOI & MOC & ULOI & MOC & ULOI & MOC \\
\hline $\begin{array}{l}\text { MQ, } 0.25 \text { in. } \\
\text { thick }\end{array}$ & 28.1 & 26 & 26.8 & 26 & 27.4 & 24 & 27.2 & 26 & 29.5 & 29 \\
\hline
\end{tabular}


Table 5. Edge effects on flammability thresholds.

\begin{tabular}{lcccc}
\hline \multirow{2}{*}{ Material } & \multicolumn{2}{c}{ Standard Mounting } & \multicolumn{2}{c}{ Exposed Edge } \\
\cline { 2 - 4 } & ULOI & MOC & ULOI & MOC \\
\hline MQ, 0.060 in. thick & 20.9 & 20 & 22.4 & 21.0 \\
PI & 27.3 & 26 & 28.6 & 27.0 \\
NBR & 16.6 & 16.1 & 16.5 & 16.1 \\
PEI & 21.9 & 21 & 22.5 & 22.0 \\
PVC sheet & 40.1 & 35 & 41.8 & 39.0 \\
\hline Notes: All samples were 7-in. long to prevent sample cave-in during test at the pass/fail criteria length. & \\
\hline
\end{tabular}

Tables 6 through 9 summarize data for selection of materials for flight experiments intended to correlate 1-g standard test data with microgravity data in ventilated spacecraft environments. The flight flammability experiments in the International Space Station (ISS) Combustion Integrated Rack (CIR) are planned to be conducted in a closed test chamber, with an approximate free volume of $75 \mathrm{~L}$. Consequently, the sample dimensions and pass/fail criteria must be small to prevent significant oxygen depletion during testing. Several criteria were used for selection of materials and test configurations for these tests, including the following:

- ULOIs and MOCs must be below 30 (30\% oxygen is the maximum oxygen concentration allowed for ISS exhaust)

- Simulate as closely as possible real-life configurations used in spacecraft (preferably flat samples; however, rod configurations might be okay). Narrow, flat samples and small-diameter rod configurations could allow opposed and concurrent-flow testing; both can allow measuring spread and regression (burning) rates. In addition, rod configurations have axisymmetric geometry that will allow easier modeling and satisfactory visualization of flight experiment burning from multiple angles.

- The lower the heat of combustion/g, the lower amount of oxygen consumed (preferable)

- Expected combustion products should not cause flame inhibition by radical scavengers (i.e., avoid halogenated compounds that may generate these)

- Charring vs. non-charring (preferably non-charring, since the samples could be reignited)

- $\quad$ Self-supporting vs. non-self-supporting (self-supporting preferable)

As expected, lowering the pass/fail burn length criteria resulted in lower oxygen concentration flammability thresholds (Table 6). As indicated, to prevent significant oxygen depletion, as well as for saving the test environment gases, the flight experiments most likely will have to be conducted using lower burn lengths for pass/fail criteria than the 6-in. used by NASA-STD-(I)-6001B Tests 1 and 4. The type of data presented in Table 6 will allow correlation of data using different pass/fail criteria in the flight experiments than in the standard 1-g tests.

Table 6. Effects of pass/fail criteria on flammability thresholds.

\begin{tabular}{|c|c|c|c|c|c|c|c|c|}
\hline \multirow[t]{4}{*}{ Material } & \multicolumn{8}{|c|}{ Pass/Fail Burn Length Criteria } \\
\hline & \multirow{2}{*}{\multicolumn{2}{|c|}{$\begin{array}{c}\text { At Least 1-in. } \\
\text { (Hot-wire Ignition) }\end{array}$}} & \multirow{2}{*}{\multicolumn{2}{|c|}{$\begin{array}{c}\text { At Least 2-in. } \\
\text { (Hot-wire Ignition) }\end{array}$}} & \multicolumn{4}{|c|}{ At Least 6-in. } \\
\hline & & & & & (Hot-h & Snition) & Chem & gniter \\
\hline & ULOI & MOC & ULOI & MOC & ULOI & MOC & ULOI & MOC \\
\hline $\mathrm{PET}^{\mathrm{a}}$ & 15.8 & 15 & 18.5 & 18 & 21.3 & 20 & 21.5 & 20 \\
\hline $\mathrm{PEI}^{\mathrm{a}}$ & 22.5 & 22 & 23.5 & 22 & 23.5 & 23 & 26.5 & 24 \\
\hline PVC 1/8-in. rod & $-{ }^{b}$ & - & $-{ }^{b}$ & - & 45.2 & 40 & & \\
\hline $\begin{array}{l}\text { PMMA, extruded, } \\
\text { 1/4-in. dia rod }\end{array}$ & $-\mathrm{b}$ & - & $-\mathrm{b}$ & - & 18.9 & 18 & 19.5 & 19 \\
\hline MQ, 0.040 in. thick & 18.6 & 18 & 21.2 & 20 & 22.5 & 21 & 23.4 & 22 \\
\hline PI & 26.3 & 25 & 27.4 & 26 & 28.7 & 27 & 27.2 & 26 \\
\hline
\end{tabular}


Burning characteristics of cast and extruded PMMA were different (Table 7). The cast does not melt extensively and maintains its dimensional stability during burning, making it ideal for flight testing where reignition of samples is desirable. Cast PMMA exhibited a stable, well-defined blue flame when ignited near self-extinction limits. Samples tested at the MOC experienced a gradual reduction in diameter with very little elongation leading to the conclusion that the rod's reduction in diameter was a result of the specimen being consumed rather than necking caused by dripping. Tests performed at this oxygen concentration often extinguished when the sample finally dripped. As the samples cooled, a slight scaling or surface deformation occurred as a result of bubbles forming just below the cooling surface. This is most likely due to the entrapment of offgassing, a result of surface cooling and subsequent hardening prior to cooling of the internal portion of the cast rod. Conversely, extruded PMMA exhibited a turbulent flame pattern when tested near MOC levels. The extruded rods dripped continuously throughout each experiment. Upon extinguishment, gases were released from below the surface of the rod to a much greater extent than the cast PMMA experiments and resulted in a grossly distorted and enlarged specimen.

Table 7. Effects of manufacturing (extrusion vs. cast) on flammability thresholds.

\begin{tabular}{lcccc}
\multicolumn{1}{c}{ Material } & \multicolumn{2}{c}{ Extruded } & \multicolumn{2}{c}{ Cast } \\
\cline { 2 - 4 } & ULOI & MOC & ULOI & MOC \\
PMMA rod, 1/4-in. dia; hot-wire ignition & 18.9 & 18 & 15.7 & 14 \\
PMMA rod, $1 / 4$-in. dia; chemical igniter & 19.5 & 19 & $-^{\mathrm{a}}$ & $-{ }^{\mathrm{a}}$ \\
\hline a Testing in progress. & & & \\
\hline
\end{tabular}

Tables 8 and 9 include information on the geometry and width effects. The information obtained indicates insignificant difference in the oxygen concentration flammability thresholds when comparing 1/8-in. dia rods with $1 / 2$-in wide samples (Table 8). With the exception of a film (PET), all materials tested in $1 / 2$-in. width samples resulted in significant reduction of oxygen concentration flammability thresholds compared with the results obtained with the 2.5-in. standard-mounted samples (Table 9).

Table 8. Effects of sample geometry on flammability thresholds.

\begin{tabular}{|c|c|c|c|c|}
\hline \multirow[t]{2}{*}{ Material } & \multicolumn{2}{|c|}{ 1/8-in. dia rod } & \multicolumn{2}{|c|}{$1 / 2$-in. wide sheet } \\
\hline & ULOI & MOC & ULOI & $\mathrm{MOC}$ \\
\hline POM (Acetron ${ }^{\circledR a} \mathrm{GP}$ ) & 12.9 & 12 & 12.3 & 11 \\
\hline $\mathrm{PP}$ & 17.6 & 16.0 & $-\mathrm{b}$ & - \\
\hline PVC & 45.2 & 40 & $-b$ & - \\
\hline PA & 21.9 (Nylon 101) & 20 (Nylon 101) & 21.6 (Zytel $\left.^{\circledR \mathrm{c}} 42\right)$ & 21 (Zytel 42) \\
\hline $\begin{array}{ll}\text { a } & \text { Acetron }{ }^{\circledR} \text { is a registered } \\
\text { b } & \text { Testing in progress. } \\
\text { c } & \text { Zytel }{ }^{\circledR} \text { is a registered tra } \\
\text { Notes: All samples were }\end{array}$ & $\begin{array}{l}\text { ademark of Polymer Co } \\
\text { emark of E. I. Du Pont } \\
\text { in. long to allow holdin }\end{array}$ & $\begin{array}{l}\text { ion, Reading, PA. } \\
\text { nours and Company, } \\
\text { e top. }\end{array}$ & ton, DE. & \\
\hline
\end{tabular}

Table 9. Effects of sample widths on flammability thresholds.

\begin{tabular}{|c|c|c|c|c|}
\hline \multirow[t]{2}{*}{ Material } & \multicolumn{2}{|c|}{ 1/2-in. Wide } & \multicolumn{2}{|c|}{ Standard 2.5-in. wide, Standard Mounting } \\
\hline & ULOI & MOC & ULOI & MOC \\
\hline PA (Zytel $\left.{ }^{\circledR a} 42\right)$ & 21.6 & 21 & 24.5 & 24.1 \\
\hline PET & 22.6 & 21 & 22.1 & 21 \\
\hline POM (Delrin $\left.{ }^{\circledR}\right)^{\mathrm{a}}$ & 12.3 & 11 & $-b$ & - \\
\hline Epoxy/glass & 17.9 & 16 & 23.6 & 23 \\
\hline PVC & $-{ }^{b}$ & - & 40.1 & 35 \\
\hline
\end{tabular}




\section{Conclusions and Recommendations}

The mode of ignition did not result in significant difference in oxygen concentration flammability thresholds; both the chemical igniter and the hot wire ignited the materials at the highest oxygen concentrations where eventually the flame extinguished. These results could have applicability for flammability testing of electronic boxes with limited free space. Using hot-wire ignition instead of chemical igniters would result in less oxygen depletion and would more closely simulate an actual ignition event.

The flammability thresholds decreased with decreasing thickness for MQ. Additional materials were evaluated to confirm this result, which validated the NASA-STD-(I)-6001B recommendation to test materials in the thinnest configuration to simulate worst thickness-usage conditions. It is suspected that the magnitude of the thickness effects depends on the magnitude of the MOC values, a hypothesis that will be verified when additional data is available. Since there could be possibilities of exceptions from the rule of "the thinner, the more flammable," further specialized tests are recommended. For example, coatings may have a minimum thickness below which the material may not ignite, possibly due to insufficient fuel available for gasification. The tests with exposed edges resulted in higher oxygen concentration thresholds than the samples tested in standard NASA-STD-(I)-6001B configuration, although the difference was very small. Only tests on PVC resulted in significant difference. Although the ULOIs for the two configurations were approximately the same, the MOC increased from 35 for the standard test configuration to 39 for the exposed edge. This somewhat surprising result will need to be confirmed with further tests. Information on edge effects and on various other ignition modes will contribute to proper selection of flammability test conditions and contribute to persuasive scientific cases for rigorous space system fire risk assessments.

As expected, lowering the pass/fail burn length criteria resulted in lower oxygen concentration flammability thresholds. As indicated, to prevent significant oxygen depletion, the flight experiments will most likely have to be conducted using lower burn lengths for pass/fail criteria than the 6-in. used by NASA-STD-(I)-6001B Tests 1 and 4. Burning characteristics of cast and extruded PMMA were different. The cast does not melt extensively and maintains its dimensional stability during burning, making it ideal for flight testing where reignition of samples is desirable. The information obtained so far indicates there is insignificant difference in the oxygen concentration flammability thresholds when comparing $1 / 8$-in. dia rods with $1 / 2$-in. wide samples. With the exception of a film (PET), all materials tested in $1 / 2$-in. width samples resulted in significant reduction of oxygen concentration flammability thresholds compared with the results obtained with the 2.5-in. standard-mounted samples.

To minimize the oxygen depletion in the flight experiments, using $1 / 8$-in. dia rods or $1 / 2$-in. wide samples and employing 1 or 2-in. burn length criteria are recommended. PMMA, POM, and PA are among the strong candidates for further evaluation in flight testing.

\section{Acknowledgments}

The authors would like to acknowledge the support provided by NASA WSTF Standard Materials Testing Branch: sample preparation (Horacio Perez, Randy Rodriguez, Steve Crowl, Mike Caro), and testing (Sam Motto, Steve Bailey, Dennis Shepan, Joe Sellers, Ricardo Madrid).

\section{Contact}

David Hirsch

NASA JSC White Sands Test Facility

P.O. Box 20

Las Cruces, New Mexico 88004

Email: david.b.hirsch@nasa.gov

\section{Notes}

*Any use of trade names in this publication is for descriptive purposes only and does not imply endorsement by the U.S. Government. 


\section{References}

${ }^{1}$ NASA. "Flammability, Offgassing, and Compatibility Requirements and Test Procedures,” NASA-STD-(I)-6001B, Test 1. NASA, Washington, DC (April 21, 2010).

${ }^{2}$ Hirsch, D. B., Williams, J. H., Haas, J. P., Beeson, H. D., Ruff, G. A., and Pedley, M. D., "Pressure Effects on the SelfExtinguishment Limits of Aerospace Materials,” $39^{\text {th }}$ International Conference on Environmental Systems, Savannah, GA, July 2009.

${ }^{3}$ Hirsch, D. B., Williams, J. H., Harper, S. A., Beeson, H. D., Ruff, G. A., and Pedley, M. D., "Pressure Flammability Thresholds in Oxygen of Selected Aerospace Materials," $40^{\text {th }}$ International Conference on Environmental Systems, Barcelona, Spain, July 2010.

${ }^{4}$ Hirsch, D. B., Motto, S., Porter, A., Beeson, H. D., and Pedley, M. D., "Issues Related to the Flammability Assessment of Polymers for Hazard Analyses of Oxygen Systems," Flammability and Sensitivity of Materials in Oxygen-Enriched Atmospheres: Tenth Volume, ASTM STP 1454, pp. 21-26, T. A. Steinberg, H. D. Beeson, and B. E. Newton, eds., ASTM International, West Conshohocken, PA, 2003.

${ }^{5}$ ASTM. Standard Test Method for Measuring the Minimum Oxygen Concentration to Support Candle-Like Combustion of Plastics (Oxygen Index), ASTM D2863-06a, American Society for Testing and Materials International, West Conshohocken, PA, 2006.

${ }^{6}$ Mell, W. E., Olson, S. L., and Kashiwagi, T., "Flame Spread Along Free Edges of Thermally Thin Samples in Microgravity,” Proceedings of the Combustion Institute, Vol. 28, 2000, pp. 2843-2849. 